\title{
Neural functions of calcineurin in synaptic plasticity and memory
}

\author{
Karsten Baumgärtel ${ }^{1}$ and Isabelle M. Mansuy ${ }^{2,3}$ \\ ${ }^{1}$ Dorris Neuroscience Center, Department of Cell Biology, The Scripps Research Institute, La Jolla, California 92037-1000, USA; ${ }^{2}$ Brain \\ Research Institute, Medical Faculty of the University of Zürich and Department of Health Science and Technology of the Swiss Federal \\ Institute of Technology, 8057 Zürich, Switzerland
}

\begin{abstract}
Major brain functions depend on neuronal processes that favor the plasticity of neuronal circuits while at the same time maintaining their stability. The mechanisms that regulate brain plasticity are complex and engage multiple cascades of molecular components that modulate synaptic efficacy. Protein kinases (PKs) and phosphatases (PPs) are among the most important of these components that act as positive and negative regulators of neuronal signaling and plasticity, respectively. In these cascades, the PP protein phosphatase $2 \mathrm{~B}$ or calcineurin $(\mathrm{CaN})$ is of particular interest because it is the only $\mathrm{Ca}^{2+}$-activated $\mathrm{PP}$ in the brain and a major regulator of key proteins essential for synaptic transmission and neuronal excitability. This review describes the primary properties of $\mathrm{CaN}$ and illustrates its functions and modes of action by focusing on several representative targets, in particular glutamate receptors, striatal enriched protein phosphatase (STEP), and neuromodulin (GAP43), and their functional significance for synaptic plasticity and memory.
\end{abstract}

The neural basis of higher-order brain functions has been the subject of intense research in the neurosciences over the past decades. This work led to the concept that major brain functions rely on brain plasticity and involve changes in synaptic efficacy. The mechanisms that underlie synaptic plasticity in the developing and adult brain are complex and depend on cascades of molecular events that engage multiple components. Protein kinases (PKs) and their counterpart enzymes, protein phosphatases (PPs), are among the most critical of these components. While PKs generally act as positive regulators of neuronal signaling and as potentiators of synaptic efficacy, PPs generally act as negative regulators that constrain synaptic efficacy. Although PKs were long considered to be more important than PPs due to their higher number (about 500 known PKs for only two dozen PPs), recent research has established that PKs and PPs are equally important for brain plasticity and are both essential components of neuronal signaling that underlie complex brain functions.

One of the major PPs in this respect is the $\mathrm{Ca}^{2+}$-dependent Ser/Thr phosphatase protein phosphatase $2 \mathrm{~B}$ or calcineurin $(\mathrm{CaN}) . \mathrm{CaN}$ is one of the most abundant PPs in the nervous system and acts on multiple substrates in synaptic, cytoplasmic, and nuclear compartments in neuronal cells. Dysregulation of $\mathrm{CaN}$ in the diseased brain is one of the major causes of pathological $\mathrm{Ca}^{2+}$ signaling associated with cognitive disorders, and of severe diseases such as Alzheimer's disease and Down syndrome (Dineley et al. 2010; Rachidi and Lopes 2010; Berridge 2011; Mohmmad Abdul et al. 2011). This review describes some of the mechanisms and biochemical targets by which $\mathrm{CaN}$ exerts its actions in synaptic plasticity and brain functions.

\section{Basic properties of $\mathrm{CaN}$}

CaN is a protein Ser/Thr phosphatase composed of a large catalytic (CaNA) and a small regulatory subunit (CaNB) (Klee et al. 1979). Its $\mathrm{Ca}^{2+}$ dependence is mediated by $\mathrm{CaNB}$ and calmodulin (CaM)

\footnotetext{
${ }^{3}$ Corresponding author

E-mail mansuy@hifo.uzh.ch

Article is online at http://www.learnmem.org/cgi/doi/10.1101/Im.027201.112.
}

(Klee et al. 1998). Upon $\mathrm{Ca}^{2+}$ binding, $\mathrm{CaNB}$ changes conformation, which induces conformational changes in CaNA and exposes the CaM binding site (Yang and Klee 2000). $\mathrm{Ca}^{2+} / \mathrm{CaM}$ then activates $\mathrm{CaN}$ by displacing CaNA's autoinhibitory domain from the catalytic domain (Shen et al. 2008). CaN has very high affinity for $\mathrm{Ca}^{2+}$ and is activated by nanomolar concentrations of $\mathrm{Ca}^{2+}$ (Cohen and Klee 1988). It can also be reversibly inactivated after prolonged $\mathrm{Ca}^{2+} / \mathrm{CaM}$ exposure (Stemmer et al. 1995; Shen et al. 2008) by, for instance, oxidation of a critical amino acid in the $\mathrm{CaM}$ binding domain of CaNA that blocks $\mathrm{Ca}^{2+} / \mathrm{CaM}$ binding and CaN activation (Carruthers and Stemmer 2008).

In the mouse, three distinct genes encode CaNA $(\alpha, \beta, \gamma)$ and have different splice variants, while only one gene encodes CaNB in two different forms $(\alpha 1, \alpha 2)$ (Kuno et al. 1989; Kincaid et al. 1990; Ueki et al. 1992; Chang et al. 1994). CaN is highly enriched in the brain (Su et al. 1995), and while several CaNA isoforms are differentially expressed in different areas (Takaishi et al. 1991; Kuno et al. 1992; Buttini et al. 1993; Chang et al. 1994), only $\mathrm{CaNB} \alpha 1$ is expressed in the brain (Ueki et al. 1992; Chang et al. 1994). In neurons, CaN protein is present in the perikarya, processes, and the nucleus (Sola et al. 1999), and is particularly enriched in synaptic terminals (Kuno et al. 1992). Different binding partners restrict $\mathrm{CaN}$ to distinct subcellular compartments, such as NFAT1 in the nucleus (Clipstone and Crabtree 1992; Luo et al. 1996; Beals et al. 1997) and AKAP scaffold proteins in dendrites (Coghlan et al. 1995; Abrenica et al. 2009). Each of the CaN subcellular pools exerts different functions and allows CaN-dependent control of neuronal structure, transcription, or neurotransmission depending on the substrates in the vicinity of $\mathrm{CaN}$ (for review, see Groth et al. 2003).

\section{$\mathrm{CaN}$ in neuronal plasticity and memory}

Experimental models of neuronal plasticity

Increased neuronal activity is associated with changes in synaptic efficacy and neuronal excitability that confer plasticity to neuronal circuits, a property necessary for memory formation. The cellular and molecular mechanisms of neuronal plasticity are complex and have been experimentally studied in different 
neuronal models. Plasticity is most commonly induced by artificial electrical stimulation of populations of neurons or axonal fibers in acute brain sections, for instance, from the hippocampus, a brain region required for spatial and episodic memory. Stimulation at high frequency increases synaptic efficacy and induces long-term potentiation (LTP), a strengthening of plasticity. In contrast, prolonged stimulation at low frequency decreases synaptic efficacy and results in long-term depression (LTD), a form of synaptic weakening. Potentiated synapses can be reset by synaptic depression and by undergoing depotentiation. Several brain regions can express LTP, LTD, and/or depotentation, and $\mathrm{CaN}$ has been shown to be involved in the underlying mechanisms, in particular, in the hippocampus. One of the most prominent actions of $\mathrm{CaN}$ is to constrain LTP. LTP is increased when CaN activity is decreased whether by antisense knockdown of CaNA (Ikegami et al. 1996), forebrain-restricted expression of a CaN inhibitor, knockout $(\mathrm{KO})$ of $\mathrm{CaNB}(\alpha 1)$ in excitatory neurons (Winder et al. 1998; Malleret et al. 2001; Zeng et al. 2001), or by pharmacological inhibition (Wang and Stelzer 1994; Wang and Kelly 1996). Conversely, LTP is impaired when CaN activity is increased by, for instance, expression of an active $\mathrm{CaN}$ in forebrain excitatory neurons (Mansuy et al. 1998b).

$\mathrm{CaN}$ is also essential for LTD and depotentiation. LTD is blocked when CaN is inhibited either pharmacologically (Mulkey et al. 1994; Hodgkiss and Kelly 1995) or by injection of a CaN autoinhibitory peptide in postsynaptic neurons (Mulkey et al. 1994). It is also strongly diminished by CaNB $(\alpha 1)$ gene KO in forebrain excitatory neurons (Zeng et al. 2001). Likewise, depotentiation is blocked by $\mathrm{CaN}$ inhibition whether achieved pharmacologically, by neuron-specific expression of a CaN inhibitor in forebrain, or by CaNA $(\alpha)$ KO (Zhuo et al. 1999; Jouvenceau et al. 2003; Kang-Park et al. 2003; Lin et al. 2003a; Jouvenceau and Dutar 2006).

Further to being essential to plasticity at excitatory synapses, $\mathrm{CaN}$ is also implicated in plasticity at inhibitory synapses. LTD at inhibitory synapses is blocked by CaN inhibition (Lu et al. 2000). Because of such a dual role in excitatory and inhibitory synapses, $\mathrm{CaN}$ manipulations that are not cell-type-specific can produce confounding results. Thus, an alteration in inhibitory synapses may oppose or interfere with an alteration in excitatory synapses at the level of a population of neurons, which may explain why CaNA $(\alpha)$ KO mice have been shown to display normal LTP and LTD (Zhuo et al. 1999), despite a clear involvement of CaN in both forms of plasticity. It may also explain why LTP is precluded if inhibitory neurotransmission is not specifically blocked during LTP induction (Lu et al. 1996). In contrast, when CaN inhibition is restricted to excitatory neurons or occurs during LTP induction, it facilitates LTP and blocks LTD (Hodgkiss and Kelly 1995; Wang and Kelly 1996; Winder et al. 1998; Malleret et al. 2001; Zeng et al. 2001; Jouvenceau et al. 2003; Jouvenceau and Dutar 2006).

\section{Experience-dependent plasticity and memory}

LTP, LTD, and depotentation are artificial models of neuronal plasticity generally used in vitro, but similar forms of plasticity have also been observed in vivo (Whitlock et al. 2006; Yoon et al. 2009; Cooke and Bear 2012). In mammals, plasticity can be induced by physiological stimuli that mimic a sensory episode. In cats and rodents, a popular model of experience-dependent plasticity is ocular dominance shift (OD) resulting from monocular deprivation (MD). OD occurs in a region of the visual cortex that receives input from both eyes. Usually, the input from the contralateral eye is stronger than from the ispilateral eye, but after occlusion of the contralateral eye during the critical period, this can be permanently reversed. OD has been shown to involve a three-step process involving plasticity: (1) the response to the oc- cluded eye is weakened through LTD-like mechanisms; (2) the threshold for synaptic activation is decreased, which favors LTP; (3) the response to the open eye is strengthened via LTP-like mechanisms (Smith et al. 2009; Yoon et al. 2009). These mechanisms are fully blocked by an increase in CaN (Yang et al. 2005), suggesting that $\mathrm{CaN}$ is likely engaged as a negative regulator of OD-dependent plasticity.

Experience-dependent plasticity is also a fundamental mechanism for learning and memory. LTP-like synaptic enhancement occurs at thalamo-cortical synapses during perceptual learning on a visual task (Cooke and Bear 2012) and in the hippocampal CA1 region during inhibitory avoidance learning (Whitlock et al. 2006). The molecular requirement for experimental models of neuronal plasticity, experience-dependent forms of plasticity, and memory overlap significantly (Izquierdo et al. 2008; Smith et al. 2009; Ye and Carew 2010; Johansen et al. 2011; Korb and Finkbeiner 2011), and altering this requirement by molecular manipulations frequently alters all three processes (Nedivi 1999). Accordingly, CaN inhibition enhances memory, whether achieved pharmacologically (Christie-Fougere et al. 2009), by expression of a $\mathrm{CaN}$ inhibitor in forebrain excitatory neurons (Malleret et al. 2001; Baumgartel et al. 2008), or through antisense oligonucleotide-mediated knockdown, applied pre-training (Ikegami and Inokuchi 2000) or post-training (Gerdjikov and Beninger 2005). Pharmacological CaN inhibition in the amygdala also blocks a specific form of learning, the extinction of associative fear memory (Lin et al. 2003a, b). In associative fear memory, mice learn to associate a conditioned stimulus (CS) that is nonaversive (a tone or context), with an unconditioned stimulus (US) that is aversive (footshock). Extinction of fear memory is achieved by repeatedly exposing the animal to the CS alone, which weakens the aversive memory trace (CS-US) and strengthens a new non-aversive memory trace (CS with no US) (Delamater 2004). Extinction relies on the relearning that a CS no longer predicts a US. This dependence on learning may explain why it involves $\mathrm{CaN}$. However, CaN may not be involved in all forms of extinction, and, for instance, it was shown that its inhibition in forebrain neurons does not affect extinction of taste aversion, another form of associative aversive memory (Baumgartel et al. 2008). Another explanation for the discrepancy between the extinction effects in the two different memory tasks may be the distinct roles of excitatory or inhibitory cells in extinction (Yee et al. 2004; Jacobson et al. 2006; Jungling et al. 2008; Sangha et al. 2009; Lin et al. 2010, 2011a; Meins et al. 2010). For studies on fear extinction, CaN was inhibited broadly and in every cell type (using a pharmacological inhibitor), while it was inhibited only in forebrain excitatory neurons in taste aversion studies, again suggesting the importance of CaN compartimentalization.

\section{$\mathrm{CaN}$ and the control of membrane receptors and channels}

The recruitment and activity of membrane receptors and voltagegated ion channels in neurons are strongly regulated by protein phosphorylation, and many receptors and channels are controlled by $\mathrm{CaN}$. The following section describes some of the most important receptors and channels targeted by $\mathrm{CaN}$, the effect of their dephosphorylation by $\mathrm{CaN}$, and their contribution to neuronal plasticity and memory.

\section{$\mathrm{CaN}$ regulates synaptic transmission in part through the AMPA receptor}

Most of the fast synaptic transmission at excitatory synapses in the brain is mediated by the glutamatergic AMPA- $(\alpha$-amino-3- 
hydroxy-5-methyl-4-isoxazolepropionic acid) receptor (AMPA-R) (Collingridge et al. 1992). In the adult brain, AMPA-Rs are usually composed of heterotetramers of GluR1, GluR2, GluR3, or GluR5 subunits. Their composition is highly dynamic (Greger et al. 2007) and greatly influences the electrophysiological features of the AMPA-R, in particular its permeability to cations, and its interaction with postsynaptic partners (for review, see Burnashev and Rozov 2000). AMPA-R activity and abundance critically affect the efficacy of glutamatergic synapses. Both activity and trafficking into and out of synapses are modulated by the phosphorylation state of the AMPA-R (Kessels and Malinow 2009). Several sites on different GluR subunits are subject to phosphorylation, but Ser845 on GluR1, a site phosphorylated by the cAMP-dependent protein kinase (PKA) (Price et al. 1999) and dephosphorylated by CaN (Fig. 1; Beattie et al. 2000), is one of the most important for AMPA-R regulation. Phosphorylated Ser845 increases AMPA-R peak response open probability (Banke et al. 2000), AMPA-R current (Roche et al. 1996), and insertion into the membrane (Man et al. 2007), and thereby strengthens synaptic transmission. In contrast, Ser845 dephosphorylation triggers AMPA-R internalization and weakens transmission (Man et al. 2007). It has therefore been suggested to be a mechanism for LTD (Lee et al. 1998). Since CaN dephosphorylates Ser845 (Beattie et al. 2000) and CaN inhibition blocks LTD (Mulkey et al. 1994; Hodgkiss and Kelly 1995; Lu et al. 2000; Zeng et al. 2001), its interaction with the AMPA-R likely constitutes an important means by which CaN regulates plasticity. This interaction involves common binding partners that are part of a postsynaptic scaffold. In this scaffold, the protein AKAP150 (Fig. 1; Gomez et al. 2002; Tavalin et al. 2002; Jurado et al. 2010) binds the AMPA-R, CaN, and PKA, and the balanced activity of CaN and PKA determines the phosphorylation state of Ser845 on GluR1. In this balance, CaN can directly dephosphorylate Ser845 but can also lead to a decrease in local kinase activity. After NMDA-R activation, it triggers the redistribution of AKAP150 and PKA from the postsynaptic membrane to the cytoplasm (Gomez et al. 2002; Smith et al. 2006). Since it re-

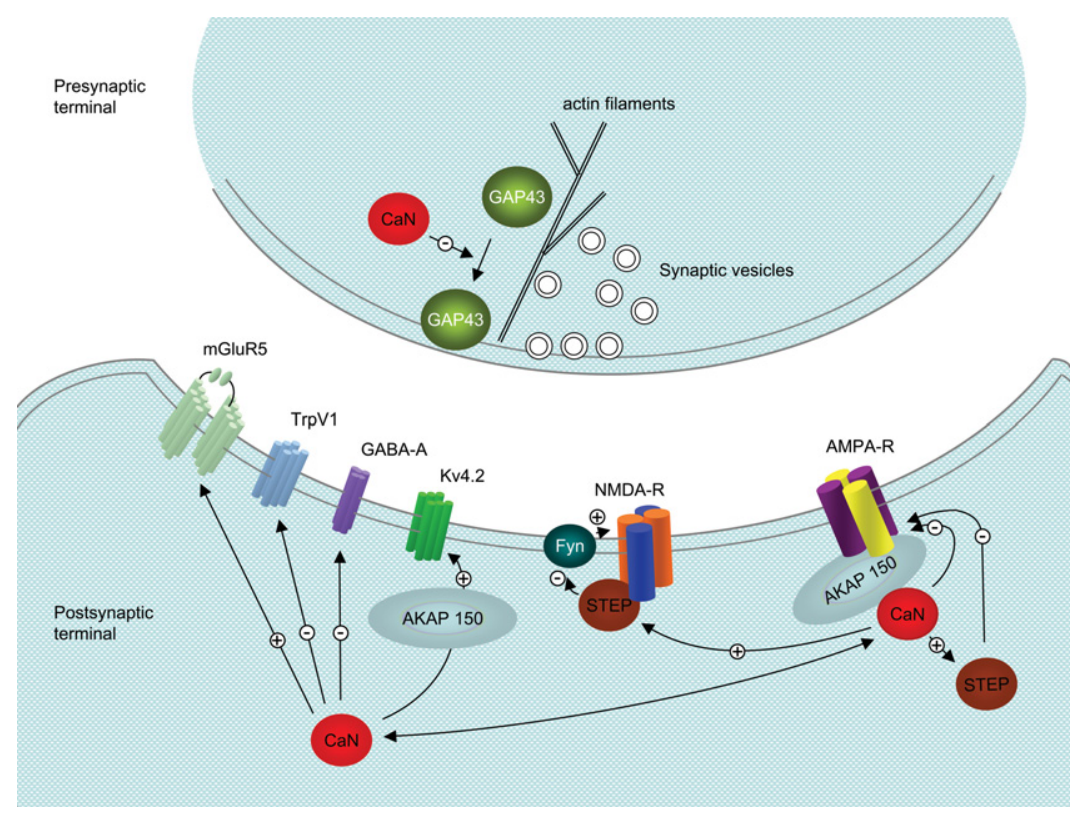

Figure 1. CaN has targets both in the pre- and the postsynaptic terminal. In the pre-synaptic terminal, the main target is GAP43. In the postsynaptic terminal, CaN either targets proteins directly or via STEP. Many proteins are dephosphorylated in an AKAP150-dependent manner. $(\oplus)$ Activates protein or increases its abundance at membrane; $(\ominus)$ inhibits protein or decreases its abundance at membrane. mains in its postsynaptic location at the same time (Gomez et al. 2002; Smith et al. 2006), this further favors dephosphorylation of GluR1, AMPA-R internalization, and decreased synaptic efficacy.

\section{CaN regulates dendritic excitability through the voltage gated A-type $\mathrm{K}^{+}$channel Kv4.2}

A target of $\mathrm{CaN}$ that contributes to its ability to regulate neuronal excitability is the voltage-gated A-type $\mathrm{K}^{+}$channel Kv4.2 (Fig. 1; Lin et al. 2011b). Kv4.2 is enriched in dendrites (Jinno et al. 2005) and specifically in postsynaptic terminals (Alonso and Widmer 1997; Gardoni et al. 2007). It is involved in neuronal repolarization after an action potential (AP) (Kim et al. 2005) and controls the amplitude of back-propagating APs in dendrites (Hoffman et al. 1997). In hippocampal slice culture, overexpression of Kv4.2 shortens AP duration and decreases back-propagation, while overexpression of dominant-negative Kv4.2 increases AP duration and enhances AP back-propagation (Kim et al. 2005). Consistently, in mice, Kv4.2 overexpression prevents LTP, while dominant-negative Kv4.2 enhances LTP (Jung et al. 2008), and Kv4.2 KO increases AP amplitude and lowers the threshold for LTP (Chen et al. 2006). Kv4.2 KO also results in deficits in spatial learning (Lockridge and Yuan 2011). Thus, much like $\mathrm{CaN}, \mathrm{Kv} 4.2$ acts as a negative regulator of neuronal plasticity. Further to its direct effects on dendritic excitability, it may also influence plasticity indirectly. Kv4.2 overexpression reduces relative synaptic NR2B/NR2A subunit ratios, while Kv4.2 blockade increases synaptic NR2B/NR2A ratios (Jung et al. 2008). An increased NR2B/NR2A ratio has been hypothesized to support plasticity (Yashiro and Philpot 2008) and/or to function as a mechanism of metaplasticity (Xu et al. 2009b). In contrast, a low NR2B/NR2A ratio likely favors CaN, and LTD over LTP (Yashiro and Philpot 2008).

One of the consequences of Kv4.2 dephosphorylation by $\mathrm{CaN}$ is its stabilization at the membrane, a process that depends on AKAP150 (Lin et al. 2011b). However, besides CaN, NMDA-R activation and $\mathrm{Ca}^{2+}$ influx can also directly control Kv4.2 and act on its internalization (Kim et al. 2007; Lei et al. 2008). The dissociation between stabilization and internalization depends on the spatial location of NMDA-R activation and $\mathrm{Ca}^{2+}$ influx. When occurring at synapses, it favors $\mathrm{Kv} 4.2$ phosphorylation and internalization (Kim et al. 2007; Hammond et al. 2008), while when occurring at extrasynaptic NMDA-R, dephosphorylation and stabilization are increased (Lei et al. 2008, 2010; Mulholland and Chandler 2010). Kv4.2 phosphorylation and internalization co-occur with AMPA-R insertion in dendritic spines (Kim et al. 2007). AMPA-R insertion and Kv4.2 internalization may thus be mediated by the identical CaN-containing complexes in response to NMDA-R activation.

Internalization of Kv4.2 also requires cleavage by calpain (Lei et al. 2010), an enzyme that participates to the internalization of different membrane receptors and signaling molecules including NMDA-R (Wu et al. 2005a; Yuen et al. 2008) and AMPA-R (Wu et al. 
2005a; Yuen et al. 2008). Calpain-mediated cleavage also contributes to generate a $\mathrm{Ca}^{2+} /$ calmodulin-independent form of CaN (Tallant et al. 1988; Wang et al. 1989). Furthermore, when activated after extrasynaptic NMDA-Rs activation, calpain can also cleave and relocate the striatal-enriched phosphatase (STEP), another CaN target (see below), from postsynaptic terminals to the cytoplasm (Xu et al. 2009a), as well as neuromodulin (GAP43), also a CaN target (see below) (Zakharov and Mosevitsky 2001).

$\mathrm{CaN}$ can further regulate Kv4.2 trafficking by an indirect mechanism involving the downstream regulatory element antagonist modulator (DREAM/KChIP3). DREAM belongs to the potassium channel-interacting protein (KChIP) family and is a direct target of CaN (Ruiz-Gomez et al. 2007). Its dephosphorylation by $\mathrm{CaN}$ is required for DREAM and Kv 4.2 membrane localization when coexpressed in cell culture (Ruiz-Gomez et al. 2007). The interaction of $\mathrm{Kv} 4.2$ and DREAM with the membrane decreases in the hippocampus after training on a hippocampal-dependent task in mice (Alexander et al. 2009), an effect associated with lower CaN activity (Havekes et al. 2006). While a direct link between this interaction and memory processes is still unclear, it is interesting to note that DREAM KO, like CaN inhibition, improves memory performance (Malleret et al. 2001; Alexander et al. 2009; Fontan-Lozano et al. 2009) and enhances LTP (Ikegami et al. 1996; Wang and Kelly 1996; Malleret et al. 2001; Zeng et al. 2001; Lilliehook et al. 2003).

\section{Other receptors and channels targeted by $\mathrm{CaN}$}

\section{The metabotropic glutamate receptor mGluR5}

The metabotropic glutamate receptor mGluR5 is a CaN target that modulates the responsiveness of neurons to different extracellular signals. Activation of mGluR5 induces phosphatidylinositol hydrolysis via phospholipase C, which releases intracellular IP3sensitive $\mathrm{Ca}^{2+}$ stores. It further activates ryanodine-sensitive $\mathrm{Ca}^{2+}$ stores and alters the activity of different voltage-gated channels (Gerber et al. 1992; Swartz and Bean 1992; Fagni et al. 2000; Sanchez-Prieto et al. 2004; Park et al. 2010; Zheng and Raman 2011). Additionally, mGluR5 activation enhances glutamate-evoked currents through the NMDA receptor (Fitzjohn et al. 1996). However, this results in a rapid desensitization of mGluR5, which is counteracted by CaN. By dephosphorylating the receptor, $\mathrm{CaN}$ can prolong its activity after glutamate release (Fig. 1; Alagarsamy et al. 2005). This effect of CaN is likely important for the induction of LTD, some forms of which rely on mGluR5 in the hippocampus (Camodeca et al. 1999; Sung et al. 2001; Huang and Hsu 2006; Naie et al. 2007; Neyman and Manahan-Vaughan 2008). But further, mGluR5 is also involved in LTP and its inhibition prevents LTP at both, excitatory (Rodrigues et al. 2002; Neyman and Manahan-Vaughan 2008) and inhibitory, synapses (Le Vasseur et al. 2008; Le Duigou et al. 2011). These effects on multiple forms of neuronal plasticity are consistent with the involvement of mGluR5 in experiencedependent plasticity in visual cortex, which requires both, LTDand LTP-like, mechanisms, through mechanisms that remain unclear (Hensch and Stryker 1996; Daw et al. 1999). mGluR5 also plays an important function in memory. Its activation in the basolateral amygdala enhances fear conditioning (Rudy and Matus-Amat 2009), while its inhibition blocks the acquisition of fear memory (Schulz et al. 2001; Rodrigues et al. 2002). Furthermore, mGluR5 inhibition in the amygdala blocks the extinction of CTA memory (Simonyi et al. 2009) similarly to CaN inhibition and may also involve LTD-like mechanisms. Together, these findings suggest that mGluR5 is likely an important mediator of CaN's action in memory regulation, through complex mechanisms that are still not fully understood.
Some of the mechanisms by which mGluR5 contributes to LTD involve activation of the vanilloid receptor TrpV1 (Bennion et al. 2011; Puente et al. 2011). TrpV1 is a non-selective cation channel highly permeable to $\mathrm{Ca}^{2+}$ and is also a direct target of CaN. But while mGluR5 prevents TrpV1 desensitization that limits the effects of repeated or persistent TrpV1 activation (Li et al. 2008), CaN favors this desensitization (Fig. 1; Mohapatra and Nau 2005). On a circuit level, this depends on whether Trpv1 is activated in excitatory or inhibitory neurons (Bennion et al. 2011). Through an indirect mechanism involving LTD at inhibitory synapses, activation of TrpV1 can facilitate LTP (Bennion et al. 2011) and suppress LTD (Li et al. 2008) in hippocampal networks. This likely reflects differential action of Trpv1 on excitatory/inhibitory circuits, reminiscent of that observed for CaN (Lu et al. 2000). Finally, further to regulating TrpV1 directly, CaN may also act downstream from this channel since it was shown to be activated by $\mathrm{Ca}^{2+}$ after TrpV1 stimulation and to regulate the activity of voltage-gated calcium channels (Wu et al. 2005b) and Kv7.2/3 (Zhang et al. 2011). Further investigation of this pathway will certainly provide interesting insight into CaN's contribution to different types of plasticity.

\section{$\mathrm{CaN}$ targets membrane receptors at inhibitory synapses}

A major property of $\mathrm{CaN}$ that makes it an essential regulator of bidirectional plasticity is its ability to control inhibitory synapses in addition to excitatory synapses (Jones and Westbrook 1997). It can bind to and dephosphorylate A-type GABA receptors $\left(\mathrm{GABA}_{\mathrm{A}}-\mathrm{R}\right)$ in an NMDA-R dependent manner (Fig. 1; Chen and Wong 1995; Robello et al. 1997; Lu et al. 2000). This dephosphorylation suppresses $\mathrm{GABA}_{\mathrm{A}}$ - $\mathrm{R}$ responses (Chen and Wong 1995), reduces inhibitory transmission (Jones and Westbrook 1997; Wang et al. 2003), and mediates LTD at inhibitory synapses (Lu et al. 2000). Reduction of GABAergic drive can disinhibit excitatory neurotransmission, thus opposing the decrease in neurotransmission mediated by $\mathrm{CaN}$ at excitatory synapses. Depending on the cellular localization of $\mathrm{CaN}$ activation, the net effect may be different. In line with its important role in shaping excitatory transmission, GABAergic inhibition has been strongly implicated in experience-dependent plasticity (Heimel et al. 2011), as well as synaptic plasticity and memory (Mohler 2007).

\section{A protein phosphatase cascade involving CaN and STEP}

Phosphorylation is an essential mechanism that allows cells to integrate information from different extracellular signals. PK cascades are ubiquitous and have multiple effector functions in many cell types. Likewise, although not as numerous as PKs, PPs can act on several sets of substrates and integrate extracellular signals. A major substrate of $\mathrm{CaN}$ that plays an important role in these cascades is STEP (Fig. 1; Paul et al. 2003). STEP is a tyrosine phosphatase present as at least six different polypeptides (Lombroso et al. 1993; Sharma and Lombroso 1995). Polypeptides of $61,46,38$, and $20 \mathrm{kDa}$ are generated by alternative splicing of the same transcript (Sharma and Lombroso 1995; Bult et al. 1997), and at least one of the shorter polypeptides (33 kDa) results from calcium-dependent cleavage of STEP61 by calpain (Nguyen et al. 1999). STEP61 (Boulanger et al. 1995; Bult et al. 1996), STEP46 (Oyama et al. 1995), and STEP38 (Bult et al. 1997) are localized to the membrane, specifically at postsynaptic terminals and in the endoplasmic reticulum, but the shortest polypeptides are predominantly in the cytoplasm and lack a catalytic domain (Boulanger et al. 1995). Cleavage may thus be a mechanism of relocating STEP to the cytoplasm and may determine its activity toward specific targets (Braithwaite et al. 2008; Xu et al. 2009a). The 
longest uncleaved splice isoforms, STEP61 and STEP46, are phosphorylated by PKA and dephosphorylated by CaN (Paul et al. 2000, 2003).

CaN and STEP are tightly linked; they are coactivated (Yang et al. 2006) and have comparable effects on LTD, LTP, and memory. Inhibition of CaN (Wang and Kelly 1996, 1997) or STEP (Pelkey et al. 2002) in postsynaptic terminals causes synaptic potentiation and occludes LTP. Conversely, overexpression of CaN or STEP impairs long-lasting LTP (Mansuy et al. 1998b; Winder et al. 1998; Pelkey et al. 2002; Paul et al. 2007). On a behavioral level, CaN or STEP inhibition improves memory (Malleret et al. 2001; Venkitaramani et al. 2011), while their overexpression disrupts learning and memory consolidation (Mansuy et al. 1998a,b; Paul et al. 2007). Interestingly, both STEP and CaN have been implicated in the molecular pathways of A $\beta$ toxicity in Alzheimer's disease (Abdul et al. 2009; Kurup et al. 2010). These findings suggest that STEP is likely an important mediator of cross talk between CaN-dependent pathways and tyrosine phosphorylation.

STEP has multiple substrates, and one of the most important for synaptic plasticity is the NMDA-R (Pelkey et al. 2002; Braithwaite et al. 2006). It can directly bind to and dephosphorylate the receptor and thereby regulate its surface expression and activity (Pelkey et al. 2002; Braithwaite et al. 2006). STEP can also modulate the NMDA-R indirectly through the membranebound Src family tyrosine kinase Fyn. STEP binding and dephosphorylation of Fyn reduce its kinase activity (Nguyen et al. 2002), which decreases NMDA-R phosphorylation and activity (Yu et al. 1997). PKA has been suggested to interfere with STEP association with Fyn (Yang et al. 2011), suggesting an important balance between CaN and PKA activity for its regulation. Further to NMDA-R, STEP is involved in AMPA-R endocytosis after activation of mGluRs 1 and 5 (group 1) (Zhang et al. 2008). This is interesting since activation of this mGluR group is sufficient to induce LTD (Camodeca et al. 1999) and suggests that the involvement of CaN in AMPA-R endocytosis and LTD induction may be both direct (see above) and indirect via STEP.

\section{CaN regulates presynaptic parameters via GAP43}

Neuronal plasticity is not restricted to mechanisms in postsynaptic terminals, but also depends on pre-synaptic processes (Powell 2006). Pre-synaptic plasticity primarily shapes the probability and the amount of neurotransmitter release triggered by a given AP. This involves synaptic vesicle-, cytoplasmic, or active zone-associated proteins that regulate vesicle availability, docking, priming, $\mathrm{Ca}^{2+}$ triggering, and even $\mathrm{Ca}^{2+}$ entry. Pre-synaptic output changes are mostly transient, and, accordingly, they support short-term plasticity. Long-term plasticity rather involves structural changes, by which the size or presence of existing synapses is altered or new synapses are formed (Gogolla et al. 2007). The growth-associated protein 43 (GAP43, neuromodulin, F1, $\mathrm{B}-50$, pp46, P-57) is a nervous system-specific protein (Kristjansson et al. 1982) that is involved in both short- and long-term presynaptic plasticity. In short-term plasticity, GAP43 may act in at least two ways. By binding rabaptin-5, an effector of the small GTPase Rab5 (Neve et al. 1998), GAP43 negatively regulates endosomal size and vesicle recycling (Neve et al. 1998). GAP43 only binds rabaptin-5 at high $\mathrm{Ca}^{2+}$ concentrations (Neve et al. 1998). At low $\mathrm{Ca}^{2+}$ concentrations, this binding is blocked by CaM (Alexander et al. 1987; Neve et al. 1998). CaM binding, in turn, is prevented by GAP43 phosphorylation, and CaM can thus be rapidly released locally through activation of the respective kinase, PKC (Van Hooff et al. 1988). This CaM release facilitates $\mathrm{Ca}^{2+} / \mathrm{CaM}$-dependent events in the pre-synaptic terminal, such as regulation of neurotransmitter release (Dekker et al. 1989) through CaMKII and Rab3A (Wang et al. 2008). CaMKII's association with $\mathrm{Ca}^{2+} / \mathrm{CaM}$ triggers its autophosphorylation, which persists even after $\mathrm{Ca}^{2+}$ levels fall and $\mathrm{Ca}^{2+} / \mathrm{CaM}$ dissociates from the enzyme (Lisman et al. 2002). Since this results in lasting CaMKII activation, it has been proposed to function as a biochemical memory trace of previous $\mathrm{Ca}^{2+}$ influx (Lisman et al. 2002). It may thus potentially serve as a transition between short- and long-term synaptic changes and/or as a substrate for long-term plasticity and memory.

GAP43's main contribution to long-term plasticity, however, is through regulation of membrane and actin dynamics. GAP43 expression is strongest and most widespread during development (Jacobson et al. 1986), when the nervous system structure is subject to extensive changes and rearrangements. Here, GAP43 regulates neurite and growth cone morphology (Aigner and Caroni 1993). GAP43 achieves this by stabilizing long actin filaments (He et al. 1997). This has been suggested to involve direct mechanisms by actin binding as well as binding to $\mathrm{PI}(4,5) \mathrm{P}_{2}$ to regulate its availability for actin binding proteins that stabilize filaments and promote growth (Laux et al. 2000). It is not required for neurite outgrowth or growth cone formation per se but for neuronal pathfinding at decision points (Strittmatter et al. 1995). Accordingly, expression of a non-phosphorylatable form of GAP43 causes ectopic axonal growth (Holahan et al. 2010). This finding suggests that GAP43 function is tightly regulated by phosphorylation. Indeed, the ability of GAP43 to stabilize actin filaments depends on its phosphorylation status (He et al. 1997). When dephosphorylated, GAP43 binds to CaM and is inactive, an event triggered by dephosphorylation by CaN (Liu and Storm 1989; Seki et al. 1995). This dephosphorylation has been proposed to underlie the inhibition of neurite outgrowth by $\mathrm{Ca}^{2+}$ waves (Lautermilch and Spitzer 2000). GAP43 is also targeted to the membrane through phosphorylation (Kristjansson et al. 1982) and specifically enriched at pre-synaptic membranes in the adult nervous system (Sorensen et al. 1981; Gispen et al. 1985).

GAP43 expression declines after synaptogenesis (Jacobson et al. 1986) except in layer 1 of cortex, the CA1 region of the hippocampus, nucleus accumbens, the amygdala, and several subcortical structures (Benowitz et al. 1988), brain regions with high plasticity. In the hippocampus, GAP43 phosphorylation is dynamically regulated by synaptic activity. It is increased immediately after LTP induction whether by high-frequency stimulation (Lovinger et al. 1986; Gianotti et al. 1992; Leahy et al. 1993; Ramakers et al. 1999) or chemical depolarization (Ramakers et al. $2000 b)$. Moreover, the extent of GAP43 phosphorylation correlates with the amount of potentiation (Lovinger et al. 1986). The increase persists for $60 \mathrm{~min}$ if induced in hippocampal slices (Ramakers et al. 1999) and for several days if induced in vivo (Routtenberg and Lovinger 1985). This supports the notion that GAP43 phosphorylation mediates long-term plasticity and memory and fits nicely with our own observation of a sustained decrease in CaN activity after learning (Baumgartel et al. 2008). Overexpression of wild-type GAP43 enhances in vivo LTP in the perforant path (Routtenberg et al. 2000), but not in the Schaffer collaterals (Hulo et al. 2002), possibly because GAP43 is still expressed in the adult CA1 (Benowitz et al. 1988). However, overexpression of a pseudophosphorylated GAP43 enhances LTP in Schaffer Collaterals (Hulo et al. 2002), which shows that GAP43 activity is more important than its level per se. In line with this, expression of a non-phosporylatable form of GAP43 has no effect on LTP induction (Routtenberg et al. 2000; Hulo et al. 2002). Pseudophosphorylated GAP43 also enhances short-term plasticity, in particular paired pulse facilitation and synaptic response summation during high-frequency stimulation (Hulo et al. 2002), demonstrating again its dual function in short- and longterm plasticity. In line with the absence of a gross morphological 
phenotype in the brain of GAP43 KO mice (Strittmatter et al. 1995), LTP in hippocampal slices is normal (Hulo et al. 2002).

Consistent with the effects of LTP, LTD induction transiently decreases GAP43 phosphorylation in a CaN-dependent manner in the CA1 region of the hippocampus when achieved by lowfrequency stimulation (Ramakers et al. 1999, 2000a), but not when achieved by NMDA incubation that will primarily induce postsynaptic plasticity (van Dam et al. 2002). With respect to natural forms of plasticity such as ocular dominance plasticity, there are currently no data implicating GAP43, except the observation that the level and phosphorylation of membrane-associated GAP43 are elevated during the critical period in cat visual cortex (McIntosh et al. 1990; Sheu et al. 1990); GAP43 association with the membrane is not altered by monocular deprivation (McIntosh et al. 1990).

However, GAP43 is strongly implicated in memory. GAP43 phosphorylation is increased after training on a memory task in the hippocampus (Cammarota et al. 1997), which correlates nicely with a reduction in CaN activity (Havekes et al. 2006). GAP43 KO mice do not survive after weaning and thus do not allow any behavioral analysis of cognitive function (Maier et al. 1999). However, heterozygous GAP43 mice have deficits in spatial learning but also have multiple sensorimotor deficits and decreased sociability, which may bias the results (Rekart et al. 2005; Zaccaria et al. 2010). Consistently, GAP43 overexpression has an effect on memory. First, it enhances learning on a working and spatial memory version of the delayed matching-to-place task in the radial arm maze (Routtenberg et al. 2000) but not on purely spatial tasks, such as contextual fear conditioning or the water maze (Holahan and Routtenberg 2008). However, it favors the extinction of contextual fear memory and enhances reversal learning in the radial arm maze (Holahan and Routtenberg 2008). Overexpression of a pseudophosphorylated GAP43 does not affect spatial learning but enhances contextual fear memory and blocks its extinction (Holahan and Routtenberg 2008). Additionally, while it does not affect learning on the radial arm maze (Routtenberg et al. 2000), it alters its reversal (Holahan and Routtenberg 2008). Overexpression of a non-phosphorylatable GAP43 also interferes with spatial learning in the water maze but not in other forms of learning (Holahan and Routtenberg 2008). These findings suggest that the phosphorylation status of GAP43 and the amount of GAP43 protein are equally important, and both need to be fine-tuned. Dysregulation of GAP43 (increase) in the hippocampus has been associated with Alzheimer's disease (Rekart et al. 2004), a finding that correlates with the CaN overactivation observed in Alzheimer's patients (Berridge 2011; Qian et al. 2011), which may further activate GAP43 and contribute to memory impairments. In summary, $\mathrm{CaN}$ is an important determinant of presynaptic neurotransmitter release and restructuring through regulation of GAP43 activity. GAP43 dephosphorylation provides an important pre-synaptic mechanism by which membrane-targeted CaN contributes to plasticity and memory.

\section{Conclusion}

$\mathrm{CaN}$ is an important regulator of neuronal plasticity in the brain that targets multiple substrates in distinct subcellular compartments. Each of these targets contributes to the functions of $\mathrm{CaN}$ in plasticity and learning and memory and has multiple and intricate relationships. Manipulations of these targets in vitro and in vivo have provided some mechanistic insight into their modes of action. However, some of CaN's functions still remain poorly understood, in particular in pathological conditions and diseases, and will therefore require more work in the future, with the hope to provide new potential targets for therapeutic treatments.

\section{Acknowledgments}

We thank Kiriana K. Cowansage for helpful comments on the manuscript. The laboratory of I.M.M. is funded by the University Zürich, the Swiss Federal Institute of Technology, the Swiss National Science Foundation, the National Center of Competence in Research "Neural Plasticity and Repair," SystemsX, and Roche.

\section{References}

Abdul HM, Sama MA, Furman JL, Mathis DM, Beckett TL, Weidner AM, Patel ES, Baig I, Murphy MP, LeVine H III, et al. 2009. Cognitive decline in Alzheimer's disease is associated with selective changes in calcineurin/NFAT signaling. J Neurosci 29: 12957-12969.

Abrenica B, AlShaaban M, Czubryt MP. 2009. The A-kinase anchor protein AKAP121 is a negative regulator of cardiomyocyte hypertrophy. J Mol Cell Cardiol 46: 674-681.

Aigner L, Caroni P. 1993. Depletion of 43-kD growth-associated protein in primary sensory neurons leads to diminished formation and spreading of growth cones. J Cell Biol 123: 417-429.

Alagarsamy S, Saugstad J, Warren L, Mansuy IM, Gereau RW IV, Conn PJ. 2005. NMDA-induced potentiation of mGluR5 is mediated by activation of protein phosphatase $2 \mathrm{~B}$ /calcineurin. Neuropharmacology 49(Suppl): $135-145$.

Alexander KA, Cimler BM, Meier KE, Storm DR. 1987. Regulation of calmodulin binding to P-57. A neurospecific calmodulin binding protein. J Biol Chem 262: 6108-6113.

Alexander JC, McDermott CM, Tunur T, Rands V, Stelly C, Karhson D, Bowlby MR, An WF, Sweatt JD, Schrader LA. 2009. The role of calsenilin/DREAM/KChIP3 in contextual fear conditioning. Learn Mem 16: $167-177$.

Alonso G, Widmer H. 1997. Clustering of KV4.2 potassium channels in postsynaptic membrane of rat supraoptic neurons: An ultrastructural study. Neuroscience 77: 617-621.

Banke TG, Bowie D, Lee H, Huganir RL, Schousboe A, Traynelis SF. 2000. Control of GluR1 AMPA receptor function by cAMP-dependent protein kinase. J Neurosci 20: 89-102.

Baumgartel K, Genoux D, Welzl H, Tweedie-Cullen RY, Koshibu K, Livingstone-Zatchej M, Mamie C, Mansuy IM. 2008. Control of the establishment of aversive memory by calcineurin and Zif268. Nat Neurosci 11: 572-578.

Beals CR, Clipstone NA, Ho SN, Crabtree GR. 1997. Nuclear localization of NF-ATc by a calcineurin-dependent, cyclosporin-sensitive intramolecular interaction. Genes Dev 11: 824-834.

Beattie EC, Carroll RC, Yu X, Morishita W, Yasuda H, von Zastrow M, Malenka RC. 2000. Regulation of AMPA receptor endocytosis by a signaling mechanism shared with LTD. Nat Neurosci 3: 1291-1300.

Bennion D, Jensen T, Walther C, Hamblin J, Wallmann A, Couch J, Blickenstaff J, Castle M, Dean L, Beckstead S, et al. 2011. Transient receptor potential vanilloid 1 agonists modulate hippocampal CA1 LTP via the GABAergic system. Neuropharmacology 61: 730-738.

Benowitz LI, Apostolides PJ, Perrone-Bizzozero N, Finklestein SP, Zwiers H. 1988. Anatomical distribution of the growth-associated protein GAP-43/B-50 in the adult rat brain. J Neurosci 8: 339-352.

Berridge MJ. 2011. Calcium signalling and Alzheimer's disease. Neurochem Res 36: 1149-1156.

Boulanger LM, Lombroso PJ, Raghunathan A, During MJ, Wahle P, Naegele JR. 1995. Cellular and molecular characterization of a brain-enriched protein tyrosine phosphatase. J Neurosci 15: $1532-1544$.

Braithwaite SP, Adkisson M, Leung J, Nava A, Masterson B, Urfer R, Oksenberg D, Nikolich K. 2006. Regulation of NMDA receptor trafficking and function by striatal-enriched tyrosine phosphatase (STEP). Eur J Neurosci 23: 2847-2856.

Braithwaite SP, Xu J, Leung J, Urfer R, Nikolich K, Oksenberg D, Lombroso PJ, Shamloo M. 2008. Expression and function of striatal enriched protein tyrosine phosphatase is profoundly altered in cerebral ischemia. Eur J Neurosci 27: 2444-2452.

Bult A, Zhao F, Dirkx R Jr, Sharma E, Lukacsi E, Solimena M, Naegele JR, Lombroso PJ. 1996. STEP61: A member of a family of brain-enriched PTPs is localized to the endoplasmic reticulum. J Neurosci 16: $7821-7831$.

Bult A, Zhao F, Dirkx R Jr, Raghunathan A, Solimena M, Lombroso PJ. 1997. STEP: A family of brain-enriched PTPs. Alternative splicing produces transmembrane, cytosolic and truncated isoforms. Eur J Cell Biol 72: 337-344.

Burnashev N, Rozov A. 2000. Genomic control of receptor function. Cell Mol Life Sci 57: 1499-1507.

Buttini M, Limonta S, Luyten M, Boddeke H. 1993. Differential distribution of calcineurin A $\alpha$ isoenzyme mRNA's in rat brain. Naunyn Schmiedebergs Arch Pharmacol 348: 679-683. 
Cammarota M, Paratcha G, Levi de Stein M, Bernabeu R, Izquierdo I, Medina JH. 1997. B-50/GAP-43 phosphorylation and PKC activity are increased in rat hippocampal synaptosomal membranes after an inhibitory avoidance training. Neurochem Res 22: 499-505.

Camodeca N, Breakwell NA, Rowan MJ, Anwyl R. 1999. Induction of LTD by activation of group I mGluR in the dentate gyrus in vitro. Neuropharmacology 38: 1597-1606.

Carruthers NJ, Stemmer PM. 2008. Methionine oxidation in the calmodulin-binding domain of calcineurin disrupts calmodulin binding and calcineurin activation. Biochemistry 47: 3085-3095.

Chang CD, Mukai H, Kuno T, Tanaka C. 1994. cDNA cloning of an alternatively spliced isoform of the regulatory subunit of $\mathrm{Ca}^{2+} /$ calmodulin-dependent protein phosphatase (calcineurin $\mathrm{B} \alpha 2$ ). Biochim Biophys Acta 1217: 174-180.

Chen QX, Wong RK. 1995. Suppression of GABAA receptor responses by NMDA application in hippocampal neurones acutely isolated from the adult guinea-pig. J Physiol 482: 353-362.

Chen X, Yuan LL, Zhao C, Birnbaum SG, Frick A, Jung WE, Schwarz TL Sweatt JD, Johnston D. 2006. Deletion of Kv4.2 gene eliminates dendritic A-type $\mathrm{K}+$ current and enhances induction of long-term potentiation in hippocampal CA1 pyramidal neurons. J Neurosci 26: 12143-12151.

Christie-Fougere MM, Darby-King A, Harley CW, McLean JH. 2009. Calcineurin inhibition eliminates the normal inverted $U$ curve, enhances acquisition and prolongs memory in a mammalian 3 '-5'-cyclic AMP-dependent learning paradigm. Neuroscience 158: 1277-1283.

Clipstone NA, Crabtree GR. 1992. Identification of calcineurin as a key signalling enzyme in T-lymphocyte activation. Nature 357: 695-697.

Coghlan VM, Perrino BA, Howard M, Langeberg LK, Hicks JB, Gallatin WM, Scott JD. 1995. Association of protein kinase A and protein phosphatase 2B with a common anchoring protein. Science 267: 108-111.

Cohen PT, Klee CB. 1988. Calmodulin. Elsevier, Amsterdam.

Collingridge GL, Randall AD, Davies CH, Alford S. 1992. The synaptic activation of NMDA receptors and $\mathrm{Ca}^{2+}$ signalling in neurons. Ciba Found Symp 164: $162-175$.

Cooke SF, Bear MF. 2012. Stimulus-selective response plasticity in the visual cortex: An assay for the assessment of pathophysiology and treatment of cognitive impairment associated with psychiatric disorders. Biol Psychiatry 71: 487-495.

Daw NW, Reid SN, Beaver CJ. 1999. Development and function of metabotropic glutamate receptors in cat visual cortex. J Neurobiol 41: $102-107$

Dekker LV, De Graan PN, Versteeg DH, Oestreicher AB, Gispen WH. 1989. Phosphorylation of B-50 (GAP43) is correlated with neurotransmitter release in rat hippocampal slices. J Neurochem 52: 24-30.

Delamater AR. 2004. Experimental extinction in Pavlovian conditioning: Behavioural and neuroscience perspectives. Q J Exp Psychol B 57: 97-132.

Dineley KT, Kayed R, Neugebauer V, Fu Y, Zhang W, Reese LC, Taglialatela G. 2010. Amyloid- $\beta$ oligomers impair fear conditioned memory in a calcineurin-dependent fashion in mice. J Neurosci Res 88: $2923-2932$.

Fagni L, Chavis P, Ango F, Bockaert J. 2000. Complex interactions between mGluRs, intracellular $\mathrm{Ca}^{2+}$ stores and ion channels in neurons. Trends Neurosci 23: 80-88.

Fitzjohn SM, Irving AJ, Palmer MJ, Harvey J, Lodge D, Collingridge GL. 1996. Activation of group I mGluRs potentiates NMDA responses in rat hippocampal slices. Neurosci Lett 203: 211-213.

Fontan-Lozano A, Romero-Granados R, del-Pozo-Martin Y, Suarez-Pereira I, Delgado-Garcia JM, Penninger JM, Carrion AM. 2009. Lack of DREAM protein enhances learning and memory and slows brain aging. Curr Biol 19: $54-60$.

Gardoni F, Mauceri D, Marcello E, Sala C, Di Luca M, Jeromin A. 2007. SAP97 directs the localization of Kv4.2 to spines in hippocampal neurons: Regulation by CaMKII. J Biol Chem 282: 28691-28699.

Gerber U, Sim JA, Gahwiler BH. 1992. Reduction of potassium conductances mediated by metabotropic glutamate receptors in rat CA3 pyramidal cells does not require protein kinase $\mathrm{C}$ or protein kinase A. Eur J Neurosci 4: 792-797.

Gerdjikov TV, Beninger RJ. 2005. Differential effects of calcineurin inhibition and protein kinase A activation on nucleus accumbens amphetamine-produced conditioned place preference in rats. Eur J Neurosci 22: 697-705.

Gianotti C, Nunzi MG, Gispen WH, Corradetti R. 1992. Phosphorylation of the presynaptic protein B-50 (GAP-43) is increased during electrically induced long-term potentiation. Neuron 8: 843-848.

Gispen WH, Leunissen JL, Oestreicher AB, Verkleij AJ, Zwiers H. 1985. Presynaptic localization of B-50 phosphoprotein: The (ACTH)-sensitive protein kinase substrate involved in rat brain polyphosphoinositide metabolism. Brain Res 328: 381-385.

Gogolla N, Galimberti I, Caroni P. 2007. Structural plasticity of axon terminals in the adult. Curr Opin Neurobiol 17: 516-524.
Gomez LL, Alam S, Smith KE, Horne E, Dell'Acqua ML. 2002. Regulation of A-kinase anchoring protein 79/150-cAMP-dependent protein kinase postsynaptic targeting by NMDA receptor activation of calcineurin and remodeling of dendritic actin. J Neurosci 22: 7027-7044.

Greger IH, Ziff EB, Penn AC. 2007. Molecular determinants of AMPA receptor subunit assembly. Trends Neurosci 30: 407-416.

Groth RD, Dunbar RL, Mermelstein PG. 2003. Calcineurin regulation of neuronal plasticity. Biochem Biophys Res Commun 311: 1159-1171.

Hammond RS, Lin L, Sidorov MS, Wikenheiser AM, Hoffman DA. 2008. Protein kinase a mediates activity-dependent Kv4.2 channel trafficking. J Neurosci 28: 7513-7519.

Havekes R, Nijholt IM, Luiten PG, Van der Zee EA. 2006. Differential involvement of hippocampal calcineurin during learning and reversal learning in a Y-maze task. Learn Mem 13: 753-759.

He Q, Dent EW, Meiri KF. 1997. Modulation of actin filament behavior by GAP-43 (neuromodulin) is dependent on the phosphorylation status of serine 41, the protein kinase C site. J Neurosci 17: 3515-3524.

Heimel JA, van Versendaal D, Levelt CN. 2011. The role of GABAergic inhibition in ocular dominance plasticity. Neural Plast 2011: 391763. doi: $10.1155 / 2011 / 391763$.

Hensch TK, Stryker MP. 1996. Ocular dominance plasticity under metabotropic glutamate receptor blockade. Science 272: 554-557.

Hodgkiss JP, Kelly JS. 1995. Only 'de novo' long-term depression (LTD) in the rat hippocampus in vitro is blocked by the same low concentration of FK506 that blocks LTD in the visual cortex. Brain Res 705: 241-246.

Hoffman DA, Magee JC, Colbert CM, Johnston D. 1997. $\mathrm{K}^{+}$channel regulation of signal propagation in dendrites of hippocampal pyramidal neurons. Nature 387: 869-875.

Holahan M, Routtenberg A. 2008. The protein kinase C phosphorylation site on GAP-43 differentially regulates information storage. Hippocampus 18: 1099-1102.

Holahan MR, Honegger KS, Routtenberg A. 2010. Ectopic growth of hippocampal mossy fibers in a mutated GAP-43 transgenic mouse with impaired spatial memory retention. Hippocampus 20: 58-64.

Huang CC, Hsu KS. 2006. Sustained activation of metabotropic glutamate receptor 5 and protein tyrosine phosphatases mediate the expression of (S)-3,5-dihydroxyphenylglycine-induced long-term depression in the hippocampal CA1 region. J Neurochem 96: 179-194.

Hulo S, Alberi S, Laux T, Muller D, Caroni P. 2002. A point mutant of GAP-43 induces enhanced short-term and long-term hippocampal plasticity. Eur J Neurosci 15: 1976-1982.

Ikegami S, Inokuchi K. 2000. Antisense DNA against calcineurin facilitates memory in contextual fear conditioning by lowering the threshold for hippocampal long-term potentiation induction. Neuroscience 98: 637-646.

Ikegami S, Kato A, Kudo Y, Kuno T, Ozawa F, Inokuchi K. 1996. A facilitatory effect on the induction of long-term potentiation in vivo by chronic administration of antisense oligodeoxynucleotides against catalytic subunits of calcineurin. Brain Res Mol Brain Res 41: 183-191.

Izquierdo I, Cammarota M, Da Silva WC, Bevilaqua LR, Rossato JI, Bonini JS, Mello P, Benetti F, Costa JC, Medina JH. 2008. The evidence for hippocampal long-term potentiation as a basis of memory for simple tasks. An Acad Bras Cienc 80: 115-127.

Jacobson RD, Virag I, Skene JH. 1986. A protein associated with axon growth, GAP-43, is widely distributed and developmentally regulated in rat CNS. J Neurosci 6: 1843-1855.

Jacobson LH, Kelly PH, Bettler B, Kaupmann K, Cryan JF. 2006. GABA B(1) $_{1}$ receptor isoforms differentially mediate the acquisition and extinction of aversive taste memories. J Neurosci 26: 8800-8803.

Jinno S, Jeromin A, Kosaka T. 2005. Postsynaptic and extrasynaptic localization of Kv 4.2 channels in the mouse hippocampal region, with special reference to targeted clustering at gabaergic synapses. Neuroscience 134: 483-494.

Johansen JP, Cain CK, Ostroff LE, LeDoux JE. 2011. Molecular mechanisms of fear learning and memory. Cell 147: 509-524.

Jones MV, Westbrook GL. 1997. Shaping of IPSCs by endogenous calcineurin activity. I Neurosci 17: 7626-7633.

Jouvenceau A, Dutar P. 2006. A role for the protein phosphatase 2B in altered hippocampal synaptic plasticity in the aged rat. J Physiol Paris 99: $154-161$.

Jouvenceau A, Billard JM, Haditsch U, Mansuy IM, Dutar P. 2003. Different phosphatase-dependent mechanisms mediate long-term depression and depotentiation of long-term potentiation in mouse hippocampal CA1 area. Eur J Neurosci 18: 1279-1285.

Jung SC, Kim J, Hoffman DA. 2008. Rapid, bidirectional remodeling of synaptic NMDA receptor subunit composition by A-type K+ channel activity in hippocampal CA1 pyramidal neurons. Neuron 60: 657-671.

Jungling K, Seidenbecher T, Sosulina L, Lesting J, Sangha S, Clark SD, Okamura N, Duangdao DM, Xu YL, Reinscheid RK, et al. 2008. Neuropeptide S-mediated control of fear expression and extinction: Role of intercalated GABAergic neurons in the amygdala. Neuron 59: 298-310. 
Jurado S, Biou V, Malenka RC. 2010. A calcineurin/AKAP complex is required for NMDA receptor-dependent long-term depression. Nat Neurosci 13: 1053-1055.

Kang-Park MH, Sarda MA, Jones KH, Moore SD, Shenolikar S, Clark S, Wilson WA. 2003. Protein phosphatases mediate depotentiation induced by high-intensity theta-burst stimulation. J Neurophysiol 89: 684-690.

Kessels HW, Malinow R. 2009. Synaptic AMPA receptor plasticity and behavior. Neuron 61: 340-350.

Kim J, Wei DS, Hoffman DA. 2005. Kv4 potassium channel subunits control action potential repolarization and frequency-dependent broadening in rat hippocampal CA1 pyramidal neurones. J Physiol 569: 41-57.

Kim J, Jung SC, Clemens AM, Petralia RS, Hoffman DA. 2007. Regulation of dendritic excitability by activity-dependent trafficking of the A-type $\mathrm{K}+$ channel subunit Kv4.2 in hippocampal neurons. Neuron 54: 933-947.

Kincaid RL, Giri PR, Higuchi S, Tamura J, Dixon SC, Marietta CA, Amorese DA, Martin BM. 1990. Cloning and characterization of molecular isoforms of the catalytic subunit of calcineurin using nonisotopic methods. J Biol Chem 265: 11312-11319.

Klee CB, Crouch TH, Krinks MH. 1979. Subunit structure and catalytic properties of bovine brain $\mathrm{Ca}^{2+}$-dependent cyclic nucleotide phosphodiesterase. Biochemistry 18: 722-729.

Klee CB, Ren H, Wang X. 1998. Regulation of the calmodulin-stimulated protein phosphatase, calcineurin. J Biol Chem 273: 13367-13370.

Korb E, Finkbeiner S. 2011. Arc in synaptic plasticity: From gene to behavior. Trends Neurosci 34: 591-598.

Kristjansson GI, Zwiers H, Oestreicher AB, Gispen WH. 1982. Evidence that the synaptic phosphoprotein B-50 is localized exclusively in nerve tissue. J Neurochem 39: 371-378.

Kuno T, Takeda T, Hirai M, Ito A, Mukai H, Tanaka C. 1989. Evidence for a second isoform of the catalytic subunit of calmodulin-dependent protein phosphatase (calcineurin A). Biochem Biophys Res Commun 165: $1352-1358$.

Kuno T, Mukai H, Ito A, Chang CD, Kishima K, Saito N, Tanaka C. 1992. Distinct cellular expression of calcineurin $A \alpha$ and $A \beta$ in rat brain. $J$ Neurochem 58: 1643-1651.

Kurup P, Zhang Y, Venkitaramani DV, Xu J, Lombroso PJ. 2010. The role of STEP in Alzheimer's disease. Channels (Austin) 4: 347-350.

Lautermilch NJ, Spitzer NC. 2000. Regulation of calcineurin by growth cone calcium waves controls neurite extension. J Neurosci 20: 315-325.

Laux T, Fukami K, Thelen M, Golub T, Frey D, Caroni P. 2000. GAP43, MARCKS, and CAP23 modulate $\mathrm{PI}(4,5) \mathrm{P}(2)$ at plasmalemmal rafts, and regulate cell cortex actin dynamics through a common mechanism. $J$ Cell Biol 149: 1455-1472.

Le Duigou C, Holden T, Kullmann DM. 2011. Short- and long-term depression at glutamatergic synapses on hippocampal interneurons by group I mGluR activation. Neuropharmacology 60: 748-756.

Le Vasseur M, Ran I, Lacaille JC. 2008. Selective induction of metabotropic glutamate receptor 1- and metabotropic glutamate receptor 5-dependent chemical long-term potentiation at oriens/alveus interneuron synapses of mouse hippocampus. Neuroscience 151: $28-42$.

Leahy JC, Luo Y, Kent CS, Meiri KF, Vallano ML. 1993. Demonstration of presynaptic protein kinase $\mathrm{C}$ activation following long-term potentiation in rat hippocampal slices. Neuroscience 52: 563-574.

Lee HK, Kameyama K, Huganir RL, Bear MF. 1998. NMDA induces long-term synaptic depression and dephosphorylation of the GluR1 subunit of AMPA receptors in hippocampus. Neuron 21: 1151-1162.

Lei Z, Deng P, Xu ZC. 2008. Regulation of Kv4.2 channels by glutamate in cultured hippocampal neurons. J Neurochem 106: 182-192.

Lei Z, Deng P, Li Y, Xu ZC. 2010. Downregulation of Kv4.2 channels mediated by NR2B-containing NMDA receptors in cultured hippocampal neurons. Neuroscience 165: 350-362.

Li HB, Mao RR, Zhang JC, Yang Y, Cao J, Xu L. 2008. Antistress effect of TRPV1 channel on synaptic plasticity and spatial memory. Biol Psychiatry 64: 286-292.

Lilliehook C, Bozdagi O, Yao J, Gomez-Ramirez M, Zaidi NF, Wasco W, Gandy S, Santucci AC, Haroutunian V, Huntley GW, et al. 2003. Altered $\mathrm{A} \beta$ formation and long-term potentiation in a calsenilin knock-out. $J$ Neurosci 23: 9097-9106.

Lin CH, Lee CC, Gean PW. 2003a. Involvement of a calcineurin cascade in amygdala depotentiation and quenching of fear memory. $\mathrm{Mol}$ Pharmacol 63: 44-52.

Lin CH, Yeh SH, Leu TH, Chang WC, Wang ST, Gean PW. 2003b. Identification of calcineurin as a key signal in the extinction of fear memory. J Neurosci 23: 1574-1579.

Lin HC, Mao SC, Su CL, Gean PW. 2010. Alterations of excitatory transmission in the lateral amygdala during expression and extinction of fear memory. Int J Neuropsychopharmacol 13: 335-345.

Lin HC, Tseng YC, Mao SC, Chen PS, Gean PW. 2011a. GABA A $_{\text {A }}$ reptor endocytosis in the basolateral amygdala is critical to the reinstatement of fear memory measured by fear-potentiated startle. J Neurosci 31: $8851-8861$.

Lin L, Sun W, Kung F, Dell'Acqua ML, Hoffman DA. 2011b. AKAP79/150 impacts intrinsic excitability of hippocampal neurons through phospho-regulation of A-type K+ channel trafficking. J Neurosci 31: 1323-1332.

Lisman J, Schulman H, Cline H. 2002. The molecular basis of CaMKII function in synaptic and behavioural memory. Nat Rev Neurosci 3: 175-190.

Liu YC, Storm DR. 1989. Dephosphorylation of neuromodulin by calcineurin. J Biol Chem 264: 12800-12804.

Lockridge A, Yuan LL. 2011. Spatial learning deficits in mice lacking A-type $\mathrm{K}^{+}$channel subunits. Hippocampus 21: $1152-1156$.

Lombroso PJ, Naegele JR, Sharma E, Lerner M. 1993. A protein tyrosine phosphatase expressed within dopaminoceptive neurons of the basal ganglia and related structures. J Neurosci 13: 3064-3074.

Lovinger DM, Colley PA, Akers RF, Nelson RB, Routtenberg A. 1986. Direct relation of long-term synaptic potentiation to phosphorylation of membrane protein F1, a substrate for membrane protein kinase C. Brain Res 399: 205-211.

Lu YF, Tomizawa K, Moriwaki A, Hayashi Y, Tokuda M, Itano T, Hatase O, Matsui H. 1996. Calcineurin inhibitors, FK506 and cyclosporin A, suppress the NMDA receptor-mediated potentials and LTP, but not depotentiation in the rat hippocampus. Brain Res 729: 142-146.

Lu YM, Mansuy IM, Kandel ER, Roder J. 2000. Calcineurin-mediated LTD of GABAergic inhibition underlies the increased excitability of CA1 neurons associated with LTP. Neuron 26: 197-205.

Luo C, Shaw KT, Raghavan A, Aramburu J, Garcia-Cozar F, Perrino BA, Hogan PG, Rao A. 1996. Interaction of calcineurin with a domain of the transcription factor NFAT1 that controls nuclear import. Proc Natl Acad Sci 93: 8907-8912.

Maier DL, Mani S, Donovan SL, Soppet D, Tessarollo L, McCasland JS, Meiri KF. 1999. Disrupted cortical map and absence of cortical barrels in growth-associated protein (GAP)-43 knockout mice. Proc Natl Acad Sci 96: $9397-9402$.

Malleret G, Haditsch U, Genoux D, Jones MW, Bliss TV, Vanhoose AM, Weitlauf C, Kandel ER, Winder DG, Mansuy IM. 2001. Inducible and reversible enhancement of learning, memory, and long-term potentiation by genetic inhibition of calcineurin. Cell 104: 675-686.

Man HY, Sekine-Aizawa Y, Huganir RL. 2007. Regulation of $\alpha$-amino-3-hydroxy-5-methyl-4-isoxazolepropionic acid receptor trafficking through PKA phosphorylation of the Glu receptor 1 subunit. Proc Natl Acad Sci 104: 3579-3584.

Mansuy IM, Mayford M, Jacob B, Kandel ER, Bach ME. 1998a. Restricted and regulated overexpression reveals calcineurin as a key component in the transition from short-term to long-term memory. Cell 92: 39-49.

Mansuy IM, Winder DG, Moallem TM, Osman M, Mayford M, Hawkins RD, Kandel ER. 1998b. Inducible and reversible gene expression with the rtTA system for the study of memory. Neuron 21: 257-265.

McIntosh H, Daw N, Parkinson D. 1990. GAP-43 in the cat visual cortex during postnatal development. Vis Neurosci 4: 585-593.

Meins M, Herry C, Muller C, Ciocchi S, Moreno E, Luthi A, Monard D. 2010 Impaired fear extinction in mice lacking protease nexin-1. Eur J Neurosci 31: $2033-2042$.

Mohapatra DP, Nau C. 2005. Regulation of $\mathrm{Ca}^{2+}$-dependent desensitization in the vanilloid receptor TRPV1 by calcineurin and cAMP-dependent protein kinase. J Biol Chem 280: 13424-13432.

Mohler H. 2007. Molecular regulation of cognitive functions and developmental plasticity: Impact of $\mathrm{GABA}_{\mathrm{A}}$ receptors. J Neurochem 102: $1-12$.

Mohmmad Abdul H, Baig I, LeVine H III, Guttmann RP, Norris CM. 2011. Proteolysis of calcineurin is increased in human hippocampus during mild cognitive impairment and is stimulated by oligomeric $A \beta$ in primary cell culture. Aging Cell 10: 103-113.

Mulholland PJ, Chandler LJ. 2010. Inhibition of glutamate transporters couples to $\mathrm{Kv} 4.2$ dephosphorylation through activation of extrasynaptic NMDA receptors. Neuroscience 165: 130-137.

Mulkey RM, Endo S, Shenolikar S, Malenka RC. 1994. Involvement of a calcineurin/inhibitor-1 phosphatase cascade in hippocampal long-term depression. Nature 369: 486-488.

Naie K, Tsanov M, Manahan-Vaughan D. 2007. Group I metabotropic glutamate receptors enable two distinct forms of long-term depression in the rat dentate gyrus in vivo. Eur J Neurosci 25: 3264-3275.

Nedivi E. 1999. Molecular analysis of developmental plasticity in neocortex. J Neurobiol 41: 135-147.

Neve RL, Coopersmith R, McPhie DL, Santeufemio C, Pratt KG, Murphy CJ, Lynn SD. 1998. The neuronal growth-associated protein GAP-43 interacts with rabaptin-5 and participates in endocytosis. J Neurosci 18: 7757-7767.

Neyman S, Manahan-Vaughan D. 2008. Metabotropic glutamate receptor 1 (mGluR1) and 5 (mGluR5) regulate late phases of LTP and LTD in the hippocampal CA1 region in vitro. Eur J Neurosci 27: 1345-1352. 
Nguyen TH, Paul S, Xu Y, Gurd JW, Lombroso PJ. 1999. Calcium-dependent cleavage of striatal enriched tyrosine phosphatase (STEP). J Neurochem 73: $1995-2001$

Nguyen TH, Liu J, Lombroso PJ. 2002. Striatal enriched phosphatase 61 dephosphorylates Fyn at phosphotyrosine 420. J Biol Chem 277: 24274-24279.

Oyama T, Goto S, Nishi T, Sato K, Yamada K, Yoshikawa M, Ushio Y. 1995. Immunocytochemical localization of the striatal enriched protein tyrosine phosphatase in the rat striatum: A light and electron microscopic study with a complementary DNA-generated polyclonal antibody. Neuroscience 69: 869-880.

Park JY, Remy S, Varela J, Cooper DC, Chung S, Kang HW, Lee JH, Spruston N. 2010. A post-burst after depolarization is mediated by group i metabotropic glutamate receptor-dependent upregulation of $\mathrm{Ca}_{\mathrm{v}} 2.3$ R-type calcium channels in CA1 pyramidal neurons. PLoS Biol 8: e1000534. doi: 10.1371/journal.pbio.1000534.

Paul S, Snyder GL, Yokakura H, Picciotto MR, Nairn AC, Lombroso PJ. 2000. The Dopamine/D1 receptor mediates the phosphorylation and inactivation of the protein tyrosine phosphatase STEP via a PKA-dependent pathway. J Neurosci 20: 5630-5638.

Paul S, Nairn AC, Wang P, Lombroso PJ. 2003. NMDA-mediated activation of the tyrosine phosphatase STEP regulates the duration of ERK signaling. Nat Neurosci 6: $34-42$.

Paul S, Olausson P, Venkitaramani DV, Ruchkina I, Moran TD, Tronson N, Mills E, Hakim S, Salter MW, Taylor JR, et al. 2007. The striatal-enriched protein tyrosine phosphatase gates long-term potentiation and fear memory in the lateral amygdala. Biol Psychiatry 61: 1049-1061.

Pelkey KA, Askalan R, Paul S, Kalia LV, Nguyen TH, Pitcher GM, Salter MW, Lombroso PJ. 2002. Tyrosine phosphatase STEP is a tonic brake on induction of long-term potentiation. Neuron 34: 127-138.

Powell CM. 2006. Gene targeting of presynaptic proteins in synaptic plasticity and memory: Across the great divide. Neurobiol Learn Mem 85: $2-15$.

Price CJ, Kim P, Raymond LA. 1999. D1 dopamine receptor-induced cyclic AMP-dependent protein kinase phosphorylation and potentiation of striatal glutamate receptors. J Neurochem 73: 2441-2446.

Puente N, Cui Y, Lassalle O, Lafourcade M, Georges F, Venance L, Grandes P, Manzoni OJ. 2011. Polymodal activation of the endocannabinoid system in the extended amygdala. Nat Neurosci 14: $1542-1547$

Qian W, Yin X, Hu W, Shi J, Gu J, Grundke-Iqbal I, Iqbal K, Gong CX, Liu F. 2011. Activation of protein phosphatase $2 \mathrm{~B}$ and hyperphosphorylation of Tau in Alzheimer's disease. J Alzheimers Dis 23: 617-627.

Rachidi M, Lopes C. 2010. Molecular and cellular mechanisms elucidating neurocognitive basis of functional impairments associated with intellectual disability in Down syndrome. Am J Intellect Dev Disabil 115: 83-112.

Ramakers GM, McNamara RK, Lenox RH, De Graan PN. 1999. Differential changes in the phosphorylation of the protein kinase $\mathrm{C}$ substrates myristoylated alanine-rich C kinase substrate and growth-associated protein-43/B-50 following Schaffer collateral long-term potentiation and long-term depression. J Neurochem 73: 2175-2183.

Ramakers GM, Heinen K, Gispen WH, de Graan PN. 2000a. Long term depression in the CA1 field is associated with a transient decrease in pre- and postsynaptic PKC substrate phosphorylation. J Biol Chem 275: 28682-28687.

Ramakers GM, Pasinelli P, van Beest M, van der Slot A, Gispen WH, De Graan PN. 2000b. Activation of pre- and postsynaptic protein kinase C during tetraethylammonium-induced long-term potentiation in the CA1 field of the hippocampus. Neurosci Lett 286: 53-56.

Rekart JL, Quinn B, Mesulam MM, Routtenberg A. 2004. Subfield-specific increase in brain growth protein in postmortem hippocampus of Alzheimer's patients. Neuroscience 126: $579-584$.

Rekart JL, Meiri K, Routtenberg A. 2005. Hippocampal-dependent memory is impaired in heterozygous GAP-43 knockout mice. Hippocampus 15: $1-7$.

Robello M, Amico C, Cupello A. 1997. A dual mechanism for impairment of GABAA receptor activity by NMDA receptor activation in rat cerebellum granule cells. Eur Biophys J 25: 181-187.

Roche KW, O'Brien RJ, Mammen AL, Bernhardt J, Huganir RL. 1996. Characterization of multiple phosphorylation sites on the AMPA receptor GluR1 subunit. Neuron 16: $1179-1188$.

Rodrigues SM, Bauer EP, Farb CR, Schafe GE, LeDoux JE. 2002. The group I metabotropic glutamate receptor mGluR5 is required for fear memory formation and long-term potentiation in the lateral amygdala. $J$ Neurosci 22: 5219-5229.

Routtenberg A, Lovinger DM. 1985. Selective increase in phosphorylation of a 47-kDa protein (F1) directly related to long-term potentiation. Behav Neural Biol 43: 3-11.

Routtenberg A, Cantallops I, Zaffuto S, Serrano P, Namgung U. 2000. Enhanced learning after genetic overexpression of a brain growth protein. Proc Natl Acad Sci 97: 7657-7662.
Rudy JW, Matus-Amat P. 2009. DHPG activation of group 1 mGluRs in BLA enhances fear conditioning. Learn Mem 16: 421-425.

Ruiz-Gomez A, Mellstrom B, Tornero D, Morato E, Savignac M, Holguin H, Aurrekoetxea K, Gonzalez P, Gonzalez-Garcia C, Cena V, et al. 2007. G protein-coupled receptor kinase 2-mediated phosphorylation of downstream regulatory element antagonist modulator regulates membrane trafficking of Kv4.2 potassium channel. J Biol Chem 282: $1205-1215$.

Sanchez-Prieto J, Paternain AV, Lerma J. 2004. Dual signaling by mGluR5a results in bi-directional modulation of $\mathrm{N}$-type $\mathrm{Ca}^{2+}$ channels. FEBS Lett 576: $428-432$.

Sangha S, Narayanan RT, Bergado-Acosta JR, Stork O, Seidenbecher T, Pape HC. 2009. Deficiency of the $65 \mathrm{kDa}$ isoform of glutamic acid decarboxylase impairs extinction of cued but not contextual fear memory. J Neurosci 29: 15713-15720.

Schulz B, Fendt M, Gasparini F, Lingenhohl K, Kuhn R, Koch M. 2001. The metabotropic glutamate receptor antagonist 2-methyl-6(phenylethynyl)-pyridine (MPEP) blocks fear conditioning in rats. Neuropharmacology 41: 1-7.

Seki K, Chen HC, Huang KP. 1995. Dephosphorylation of protein kinase C substrates, neurogranin, neuromodulin, and MARCKS, by calcineurin and protein phosphatases 1 and 2A. Arch Biochem Biophys 316: 673-679.

Sharma E, Lombroso PJ. 1995. A neuronal protein tyrosine phosphatase induced by nerve growth factor. I Biol Chem 270: 49-53.

Shen X, Li H, Ou Y, Tao W, Dong A, Kong J, Ji C, Yu S. 2008. The secondary structure of calcineurin regulatory region and conformational change induced by calcium/calmodulin binding. J Biol Chem 283: $11407-11413$.

Sheu FS, Kasamatsu T, Routtenberg A. 1990. Protein kinase C activity and substrate (F1/GAP-43) phosphorylation in developing cat visual cortex. Brain Res 524: $144-148$.

Simonyi A, Serfozo P, Parker KE, Ramsey AK, Schachtman TR. 2009. Metabotropic glutamate receptor 5 in conditioned taste aversion learning. Neurobiol Learn Mem 92: 460-463.

Smith KE, Gibson ES, Dell'Acqua ML. 2006. cAMP-dependent protein kinase postsynaptic localization regulated by NMDA receptor activation through translocation of an A-kinase anchoring protein scaffold protein. J Neurosci 26: 2391-2402.

Smith GB, Heynen AJ, Bear MF. 2009. Bidirectional synaptic mechanisms of ocular dominance plasticity in visual cortex. Philos Trans $R$ Soc Lond B Biol Sci 364: 357-367.

Sola C, Tusell JM, Serratosa J. 1999. Comparative study of the distribution of calmodulin kinase II and calcineurin in the mouse brain. J Neurosci Res 57: 651-662.

Sorensen RG, Kleine LP, Mahler HR. 1981. Presynaptic localization of phosphoprotein B-50. Brain Res Bull 7: 57-61.

Stemmer PM, Wang X, Krinks MH, Klee CB. 1995. Factors responsible for the $\mathrm{Ca}^{2+}$-dependent inactivation of calcineurin in brain. FEBS Lett 374: 237-240.

Strittmatter SM, Fankhauser C, Huang PL, Mashimo H, Fishman MC. 1995. Neuronal pathfinding is abnormal in mice lacking the neuronal growth cone protein GAP-43. Cell 80: $445-452$.

Su Q, Zhao M, Weber E, Eugster HP, Ryffel B. 1995. Distribution and activity of calcineurin in rat tissues. Evidence for posttranscriptional regulation of testis-specific calcineurin B. Eur J Biochem 230: 469-474.

Sung KW, Choi S, Lovinger DM. 2001. Activation of group I mGluRs is necessary for induction of long-term depression at striatal synapses. J Neurophysiol 86: 2405-2412.

Swartz KJ, Bean BP. 1992. Inhibition of calcium channels in rat CA3 pyramidal neurons by a metabotropic glutamate receptor. J Neurosci 12: $4358-4371$.

Takaishi T, Saito N, Kuno T, Tanaka C. 1991. Differential distribution of the mRNA encoding two isoforms of the catalytic subunit of calcineurin in the rat brain. Biochem Biophys Res Commun 174: 393-398.

Tallant EA, Brumley LM, Wallace RW. 1988. Activation of a calmodulin-dependent phosphatase by a $\mathrm{Ca}^{2+}$-dependent protease. Biochemistry 27: 2205-2211.

Tavalin SJ, Colledge M, Hell JW, Langeberg LK, Huganir RL, Scott JD. 2002. Regulation of GluR1 by the A-kinase anchoring protein 79 (AKAP79) signaling complex shares properties with long-term depression. J Neurosci 22: 3044-3051.

Ueki K, Muramatsu T, Kincaid RL. 1992. Structure and expression of two isoforms of the murine calmodulin-dependent protein phosphatase regulatory subunit (calcineurin B). Biochem Biophys Res Commun 187: $537-543$.

van Dam EJ, Ruiter B, Kamal A, Ramakers GM, Gispen WH, de Graan PN. 2002. N-methyl-D-aspartate-induced long-term depression is associated with a decrease in postsynaptic protein kinase C substrate phosphorylation in rat hippocampal slices. Neurosci Lett 320: $129-132$. 
Van Hooff CO, De Graan PN, Oestreicher AB, Gispen WH. 1988. B-50 phosphorylation and polyphosphoinositide metabolism in nerve growth cone membranes. J Neurosci 8: 1789-1795.

Venkitaramani DV, Moura PJ, Picciotto MR, Lombroso PJ. 2011. Striatal-enriched protein tyrosine phosphatase (STEP) knockout mice have enhanced hippocampal memory. Eur J Neurosci 33: 2288-2298.

Wang JH, Kelly PT. 1996. The balance between postsynaptic $\mathrm{Ca}^{2+}$-dependent protein kinase and phosphatase activities controlling synaptic strength. Learn Mem 3: 170-181.

Wang JH, Kelly PT. 1997. Postsynaptic calcineurin activity downregulates synaptic transmission by weakening intracellular $\mathrm{Ca}^{2+}$ signaling mechanisms in hippocampal CA1 neurons. J Neurosci 17: 4600-4611.

Wang JH, Stelzer A. 1994. Inhibition of phosphatase 2B prevents expression of hippocampal long-term potentiation. Neuroreport 5: 2377-2380.

Wang KK, Roufogalis BD, Villalobo A. 1989. Characterization of the fragmented forms of calcineurin produced by calpain I. Biochem Cell Biol 67: 703-711.

Wang J, Liu S, Haditsch U, Tu W, Cochrane K, Ahmadian G, Tran L, Paw J, Wang Y, Mansuy I, et al. 2003. Interaction of calcineurin and type-A GABA receptor $\gamma 2$ subunits produces long-term depression at CA1 inhibitory synapses. J Neurosci 23: 826-836.

Wang X, Thiagarajan R, Wang Q, Tewolde T, Rich MM, Engisch KL. 2008. Regulation of quantal shape by Rab3A: Evidence for a fusion pore-dependent mechanism. J Physiol 586: 3949-3962.

Whitlock JR, Heynen AJ, Shuler MG, Bear MF. 2006. Learning induces long-term potentiation in the hippocampus. Science 313: 1093-1097.

Winder DG, Mansuy IM, Osman M, Moallem TM, Kandel ER. 1998. Genetic and pharmacological evidence for a novel, intermediate phase of long-term potentiation suppressed by calcineurin. Cell 92: 25-37.

Wu HY, Yuen EY, Lu YF, Matsushita M, Matsui H, Yan Z, Tomizawa K. 2005a. Regulation of $N$-methyl-D-aspartate receptors by calpain in cortical neurons. J Biol Chem 280: 21588-21593.

Wu ZZ, Chen SR, Pan HL. 2005b. Transient receptor potential vanilloid type 1 activation down-regulates voltage-gated calcium channels through calcium-dependent calcineurin in sensory neurons. J Biol Chem 280: $18142-18151$.

Xu J, Kurup P, Zhang Y, Goebel-Goody SM, Wu PH, Hawasli AH, Baum ML, Bibb JA, Lombroso PJ. 2009a. Extrasynaptic NMDA receptors couple preferentially to excitotoxicity via calpain-mediated cleavage of STEP. J Neurosci 29: 9330-9343.

Xu Z, Chen RQ, Gu QH, Yan JZ, Wang SH, Liu SY, Lu W. 2009b. Metaplastic regulation of long-term potentiation/long-term depression threshold by activity-dependent changes of NR2A/NR2B ratio. J Neurosci 29: 8764-8773.

Yang SA, Klee CB. 2000. Low affinity $\mathrm{Ca}^{2+}$-binding sites of calcineurin B mediate conformational changes in calcineurin A. Biochemistry 39: $16147-16154$

Yang Y, Fischer QS, Zhang Y, Baumgartel K, Mansuy IM, Daw NW. 2005. Reversible blockade of experience-dependent plasticity by calcineurin in mouse visual cortex. Nat Neurosci 8: 791-796.
Yang CH, Huang CC, Hsu KS. 2006. Novelty exploration elicits a reversal of acute stress-induced modulation of hippocampal synaptic plasticity in the rat. J Physiol 577: 601-615.

Yang HB, Yang X, Cao J, Li S, Liu YN, Suo ZW, Cui HB, Guo Z, Hu XD. 2011. cAMP-dependent protein kinase activated Fyn in spinal dorsal horn to regulate NMDA receptor function during inflammatory pain. $J$ Neurochem 116: 93-104.

Yashiro K, Philpot BD. 2008. Regulation of NMDA receptor subunit expression and its implications for LTD, LTP, and metaplasticity. Neuropharmacology 55: 1081-1094.

Ye X, Carew TJ. 2010. Small G protein signaling in neuronal plasticity and memory formation: The specific role of ras family proteins. Neuron 68: $340-361$.

Yee BK, Hauser J, Dolgov VV, Keist R, Mohler H, Rudolph U, Feldon J. 2004. GABA receptors containing the alpha5 subunit mediate the trace effect in aversive and appetitive conditioning and extinction of conditioned fear. Eur J Neurosci 20: 1928-1936.

Yoon BJ, Smith GB, Heynen AJ, Neve RL, Bear MF. 2009. Essential role for a long-term depression mechanism in ocular dominance plasticity. Proc Natl Acad Sci 106: 9860-9865.

Yu XM, Askalan R, Keil GJ II, Salter MW. 1997. NMDA channel regulation by channel-associated protein tyrosine kinase Src. Science 275: $674-678$.

Yuen EY, Ren Y, Yan Z. 2008. Postsynaptic density-95 (PSD-95) and calcineurin control the sensitivity of $N$-methyl-D-aspartate receptors to calpain cleavage in cortical neurons. Mol Pharmacol 74: 360-370.

Zaccaria KJ, Lagace DC, Eisch AJ, McCasland JS. 2010. Resistance to change and vulnerability to stress: Autistic-like features of GAP43-deficient mice. Genes Brain Behav 9: 985-996.

Zakharov VV, Mosevitsky MI. 2001. Site-specific calcium-dependent proteolysis of neuronal protein GAP-43. Neurosci Res 39: 447-453.

Zeng H, Chattarji S, Barbarosie M, Rondi-Reig L, Philpot BD, Miyakawa T, Bear MF, Tonegawa S. 2001. Forebrain-specific calcineurin knockout selectively impairs bidirectional synaptic plasticity and working/ episodic-like memory. Cell 107: 617-629.

Zhang Y, Venkitaramani DV, Gladding CM, Kurup P, Molnar E, Collingridge GL, Lombroso PJ. 2008. The tyrosine phosphatase STEP mediates AMPA receptor endocytosis after metabotropic glutamate receptor stimulation. J Neurosci 28: 10561-10566.

Zhang XF, Han P, Neelands TR, McGaraughty S, Honore P, Surowy CS, Zhang D. 2011. Coexpression and activation of TRPV1 suppress the activity of the KCNQ2/3 channel. J Gen Physiol 138: 341-352.

Zheng N, Raman IM. 2011. Prolonged postinhibitory rebound firing in the cerebellar nuclei mediated by group I metabotropic glutamate receptor potentiation of L-type calcium currents. J Neurosci 31: 10283-10292.

Zhuo M, Zhang W, Son H, Mansuy I, Sobel RA, Seidman J, Kandel ER. 1999. A selective role of calcineurin $A \alpha$ in synaptic depotentiation in hippocampus. Proc Natl Acad Sci 96: 4650-4655.

Received May 22, 2012; accepted in revised form June 6, 2012. 


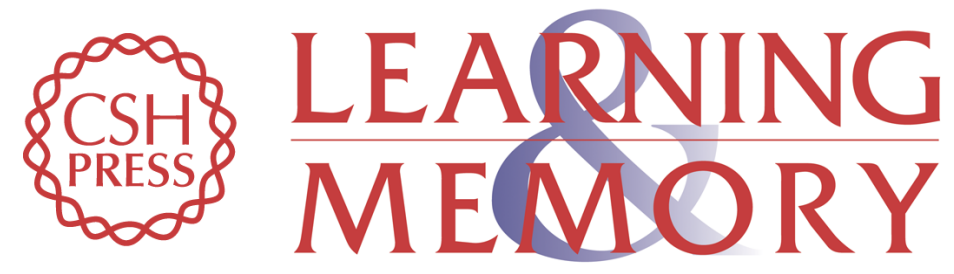

\section{Neural functions of calcineurin in synaptic plasticity and memory}

Karsten Baumgärtel and Isabelle M. Mansuy

Learn. Mem. 2012, 19:

Access the most recent version at doi:10.1101//m.027201.112

References This article cites 201 articles, 64 of which can be accessed free at: http://learnmem.cshlp.org/content/19/9/375.full.html\#ref-list-1

License

Email Alerting Receive free email alerts when new articles cite this article - sign up in the box at the Service top right corner of the article or click here. 